\title{
MATHATICS AS PEDAGOGY, IN THE HISTORY OF PEDAGOGY AND EDUCATION
}

\author{
Yulduzkhon Kulnazarovna Kushnazarova
}

Lecturer, Chirchik State Pedagogical Institute, Tashkent Region, Uzbekistan

\section{ABSTRACT}

Global paradigms "cover all types of activity and underlie the shift from the deterministic stochastic and to the third synergetic paradigm." The paradigm can be described using three keywords: self-organization, open systems, non-linearity. This work uses the data tabulation method and the graphical presentation of the results.

The philosophy of postmodernism is a motor speech between a person and his reality. The value of education is not to memorize facts, to encourage the brain to think. In other words, postmodernism is "a new model of thinking that refuses to embrace traditionalism without reflection and reappraisal." In postmodernism, all similar, different and non-traditional data and knowledge coexist. Thus, if in modernism educational services are important, if they are useful, then in postmodernism the usefulness of a product or service is determined by the emotions of the person for whom the product was created. From this point of view, the educational product and service should be memorable.

KEYWORDS: - Pedagogy, mathematics, pradigma, philosophy, education, modernization, modernization, analysis, teaching.

\section{INTRODUCTION}

The methodology of science is the teaching of the methods and procedures of scientific activity. In the applied sense, a methodology is a system (complex, totality) of principles and approaches of research activity, on which a researcher relies in the course of obtaining and developing knowledge within a specific discipline. The term methodology is of Greek origin and means "teaching about method" or "theory of method". The most significant contributions to the development of the methodology of science were made by Plato, Aristotle, Bacon, Descartes, Kant, Hegel and other classics of philosophy. Aristotle and Bacon classified scientific knowledge and proposed two main methods for obtaining reliable information about nature and man: logical-deductive and experimentally inductiv. Kant developed the general boundaries of cognitive abilities, and Schelling and Hegel attempted to create a universal system of scientific knowledge. In the works of Comte, Spencer, Durkheim and others, specific variants of methods of scientific and cognitive activity are presented, focused mainly on the aspect of social ties and relationships. In the field of logical and mathematical knowledge, the studies of Boulle, Frege, Peirce were of particular importance in the formation of the methodology of science In modern science, methodology is understood in the narrow and broad sense of the word. In a broad sense, methodology is a set of the most general, primarily worldview, principles in their 
CURRENT RESEARCH JOURNAL OF PEDAGOGICS 2(8): 110-116, August

2021 DOI: https://doi.org/10.37547/pedagogics-crjp-02-08-24

ISSN 2767-3278

(C)2021 Master Journals

\section{Crossref do) 81 Google}

Accepted $26^{\text {th }}$ August, 2021 \& Published 31 th August, 2021

application to solving complex theoretical and practical problems; this is the worldview position of the researcher; it is also the doctrine of the methods of cognition, which substantiates the initial principles and methods of their concrete application in cognitive and practical activity. Methodology in the narrow sense of the word is the teaching about the methods of scientific research. The methodology of science characterizes the components of a scientific research - its object, subject, research tasks, a set of research methods, means and methods necessary for their solution, and also forms an idea of the sequence of movement of the researcher in the process of solving a scientific problem. The task of the methodology of science is to identify and comprehend the driving forces, prerequisites, foundations and patterns of growth and functioning of scientific knowledge and cognitive activity, to organize design and constructive activity, its analysis and criticism. In the structure of methodological knowledge E.G. Yudin identified four levels: philosophical, general scientific, specific scientific and technological. The content of the philosophical level of methodology is made up of the general principles of cognition and the categorical structure of science as a whole (methodological functions are performed by the entire system of philosophical knowledge).

The general scientific level is the theoretical framework applied to all or most scientific disciplines. Specific scientific methodology - a set of methods, research principles and procedures used in a particular special scientific discipline. Technological methodology is a methodology and research technique (a set of procedures that ensure the receipt of reliable empirical material and its primary processing, after which it can be included in the body of scientific knowledge). All levels of pedagogical methodology form a complex system. The methodology of the pedagogy of the acting function: provides methods of teaching scientific knowledge that reflect the constantly changing pedagogy (MA Danilov); directs and predetermines the main path through which a specific research goal is achieved (P.V. Koppin); - provides comprehensiveness of obtaining information about the studied process or phenomenon; creates a system of information based on objective facts and a logical-analytical tool of scientific knowledge (M.N. Skatkin);- -helps to introduce new information into the fund of the theory of pedagogy (F.F.Korolev); - provides clarification, enrichment, systematization of terms and concepts in pedagogical science (V.E. Gmurman). 26 The methodology of pedagogy is a conceptual statement of the goal, research methods, the use of the most objective, accurate, systematized information about pedagogical processes and phenomena. The methodology of pedagogy is a system of foundations and a structure of pedagogical theory, principles of approach and methods of knowledge that reflect pedagogical reality, as well as a system of activities for obtaining such knowledge and substantiating programs, logic and methods, assessing the quality of special scientific pedagogical research. The methodology of pedagogy has two aspects: one of them is associated with knowledge as a result of cognitive activity, and the second - with this activity. This refers to two types of activities methodological research and methodological support. The first task is to identify patterns and trends in the development of pedagogical in its connection with practice, the principles of improving the quality of pedagogical research, and analysis of their conceptual composition and methods. The challenge is to use applied methodological knowledge to justify the research program and assess its quality when it is underway or has already been completed. These differences determine the allocation of two functions of the methodology of pedagogy: 
CURRENT RESEARCH JOURNAL OF PEDAGOGICS 2(8): 110-116, August

2021 DOI: https://doi.org/10.37547/pedagogics-crjp-02-08-24

ISSN 2767-3278

(C)2021 Master Journals

\section{Crossref do) 81 Google}

Accepted $26^{\text {th }}$ August, 2021 \& Published 31 th August, 2021

descriptive (also presupposing the formation of a theoretical description of the object); and normative (creating guidelines for the work of a teacher-researcher). The presence of these functions also determines the division of the foundations of pedagogical methodology into two groups (theoretical and normative). Scientific and pedagogical knowledge is fixed in pedagogical concepts, theories and paradigms. The strategy in scientific-pedagogical and scientific-psychological knowledge was called "paradigm". Paradigm - a model for posing problems and solving them, research methods that have dominated over a certain historical period in the scientific community; a leading idea serving as a model for the construction of scientific theories and concepts. All the variety of modern scientific and pedagogical ideas is recorded in three leading educational paradigms. These paradigms differ mainly in the understanding of the goals of education and the corresponding goals of research in the field of education, on which the choice of research tools depends (they are used to solve the problems of methodological approaches, methods and techniques of research, a system of diagnostic techniques, methods of processing the research obtained in the course of research and presenting research findings ).

Training, and they were: subject teachers, elementary school teachers, speech therapists, educational psychologists, administrators of various levels - it was proposed to give their assessments and determine reflections on the educational material.

It is natural to assume that the analysis of the results of the discussion was not identical for different categories of students. The latter is due to the practical orientation of the activities of teachers, their interests and competencies. In the subject-activity approach and in accordance with the transdisciplinary methodology developed by the school of Professor V.S. Meskov (Moscow
State Pedagogical University, Higher School of Economics), the formation of competencies and competencies of pedagogical activity is supposed. The tables for each of the 49 techniques by Doug Lemov present the analysis and reflections of teachers, chosen by the author as the most clearly formulated and justified in assessing the material being analyzed.

Having studied the prototype - the initial state of affairs, the teacher always builds a model of his activity, including methodological. Then this model is adapted based on the specific educational tasks to be solved. If successful, such a model is taken as a basis. Further, based on feedback, it is tested in other areas of activity. If necessary, further explication and correction is carried out. As a result, the obtained results are transferred to the prototype, which is the result of the creation of a methodically systematized educational space. Naturally, in this approach, the participants in the educational process are considered as subjects, which makes it possible to put forward a hypothesis about the nonclassical nature of the relationship between them.

Let us present the results obtained, using the classification of D. Lemov, personifying the assessments of the teachers and fixing the areas of applicability. The article sequentially sets out: a description of the methodology itself according to D. Lemov, a brief presentation of this methodology in the presentation of teachers, indicating their position in an educational institution; a qualitative assessment of the applicability and effectiveness of this methodology in the work of the teacher himself and his colleagues.

In total, the text contains seven blocks, which combine "related techniques", i.e. methods that allow solving the same type of tasks of conducting lessons. In accordance with D. Lemov's approach, the considered blocks of 
CURRENT RESEARCH JOURNAL OF PEDAGOGICS 2(8): 110-116, August

2021 DOI: https://doi.org/10.37547/pedagogics-crjp-02-08-24

ISSN 2767-3278

(C)2021 Master Journals

\section{Crossref doi) 81 Google}

Accepted $26^{\text {th }}$ August, 2021 \& Published 31 th August, 2021

techniques are "tied" to the so-called classroomlesson system. In conclusion, for each of the blocks of techniques, a short author's expert summary is provided.

"Formal learning means learning that takes place in an organized and structured environment specifically dedicated to learning and usually results in the award of a qualification in the form of a certificate or diploma; it includes the systems of general education, vocational education and higher education ...

Non-formal learning means learning that is delivered through planned activities (in terms of learning objectives, learning time); ... it can encompass programs for the dissemination of work skills, adult literacy and basic education for early childhood graduates; ... enterprise and courses organized by a civil society organization for its members, their target group or the general public ...

Informal learning means learning as a result of daily activities related to work, family or leisure, and is not organized or structured in terms of goals, timing or support for learning; these are skills acquired through life experience and work experience; ... skills acquired through volunteering, cultural activities, sports, youth work and home activities "1.

You can find more about the definition and main characteristics of the constituent parts of the educational triad in our other publication2.

The first two terms of the educational triad "formal" and "non-formal education" - are well known in the Russian educational space. What is the frequency of use of the term "informal education" in Russian scientific literature?

"Informal education" is found in the title of one doctoral and two master's theses defended outside Moscow (Nizhny Novgorod, Orenburg, Veliky Novgorod), in more than 100 scientific developments. The term "informal education" is found in the texts of 82 dissertations in 12 different specialties (most of them have a specialty code 13.00.01 "General pedagogy, history of pedagogy and education") and in more than 460 scientific papers. Mentors who enrich students with intelligence are primarily a part of non-formal education - "this is learning that is carried out through planned activities (in terms of learning goals, learning time)". And the authority that enriches learners is teachers or formal education teachers - this is "learning that takes place in an organized and structured environment specifically dedicated to learning."

Why is informal education the mathematics of the 21 st century?

Because this type of education in the fullest extent corresponds to the task set by Comenius: "It is necessary to educate everyone, throughout life ..." And, most importantly: "Educational activity takes place in the image and likeness of the activity of nature-creator. Nature does not cause violence Each activity in the life process leads to the acquisition of new knowledge or the development of skills. The philosophical explanation for this is that at each subsequent moment a person is different from what he was in the previous one. In this sense, informal education is a constant stream of personal innovation.

And if in the future we have to talk more and more about informal education, what happens to formal education?

An essential feature of modern formal education is the pressure it experiences as a result of pupils acquiring skills through informal education using modern means of communication and discrediting teachers who do not know them. Because of this, it makes no sense for some young people to attend school when all knowledge is available outside the educational institution. 
CURRENT RESEARCH JOURNAL OF PEDAGOGICS 2(8): 110-116, August

2021 DOI: https://doi.org/10.37547/pedagogics-crjp-02-08-24

ISSN 2767-3278

(C)2021 Master Journals

\section{Crossref do) 81 Google}

Accepted 26 th August, 2021 \& Published 31 th August, 2021

Formal education will always occupy only a part of our life, and our "discipleship" is for life (lifelong learning - learning throughout life). The very formulation of a lifelong learning program brings a deep existential meaning: life is learning or learning is life.

The natural driver of this program can be informal education as a successful life. Because it is not limited by the conventions of formal education (you know, but you are not sure if you can), and the acquired skills of informal education are visible in life itself.

What are the benefits of informal education as a personal asset? In the countries of the European Union, it is already the subject of a very popular certification (validation) procedure. Certification (validation) of informal learning experience as a unique achievement of an individual should allow him to improve his educational level or obtain professional status. Here we will show the experience of the Republic of Bulgaria as a member of the EU.

The term "informal learning" was introduced with our active participation in the following regulations:

- Law on Preschool and School Education;

- Law on Vocational Education and Training;

- Law on the Promotion of Employment.

In 2013-2014 The Ministry of Education and Science of Bulgaria is implementing the project "New Opportunity for My Future".

One of the goals of the project is to expand opportunities for obtaining professional qualifications in order to increase employability. A system was created to identify and recognize informally and informally acquired knowledge, skills and competencies. A wide popularization of opportunities for validation of informally and informally acquired knowledge, skills and competences among the Bulgarian public was carried out.

It is important to create a Universal Pedagogy - a theory of teaching pansophical (Universal Wisdom) knowledge and a way of life, in which Ya.A. Comenius, in particular, substantiated the need for "universal education" and "open access to education."

In education, the active activity of the student himself is important: in fact, Comenius is the founder of the "activity" and "competence" approaches.

We have drawn attention to the following common interpretation of some of Comenius's proposals. The classroom-lesson system Komensky conceived is not at all the same as its embodiment in a modern school: "After all, the dignity and distinctive feature of this correct Method (Didactics) is that the students do not get confused in anything, but by mutual examples and competition among themselves encouraged would push themselves, focus each other's attention and, by the force of mutual persuasion, would lead everyone to the goal of their education, if only all together, at the same time they would be engaged in the same subject and would all strive to the same extent to the same , and in this striving we would do everything together. However, one should not forget about personal intentions ..."

Failure to comply even with such elementary positions of the Great Didactics of Comenius in the practice of the Russian school has lowered pedagogy from the rank of "the art of teaching" to "nonscience". A simplified understanding of the class-lesson system also led to more serious negative results - "silent generations" of obedient "slaves", while Comenius strove to give each person the tools of "creation". One of such tools is Matetica - the science of Discipleship as cognition.

REFERENCES 
CURRENT RESEARCH JOURNAL OF PEDAGOGICS 2(8): 110-116, August

2021 DOI: https://doi.org/10.37547/pedagogics-crjp-02-08-24

ISSN 2767-3278

(C)2021 Master Journals

Crossref do: 81 Google

Accepted $26^{\text {th }}$ August, 2021 \& Published 31 th August, 2021

1. Higher Education in a Globalized Society: UNESCO Education Policy / United Nations Educational, Scientific and Cultural Organization. - 2004 .-- 32 p. ED-2004 / WS / 33.

2. Gorbunova L. The keys to the competence of the transnational sanctuary space: design and implementation // Philosophy of education. Philosophy of Education. 2016. - Vol. 2 (19). - P. 97-117.

3. Умарова М.Теория и история педагогики. -Т.:"Чўлпон".2018.-с 202

4. Педагогик атамалар луғати. Р.Жўраев ва бошқ. - Т. “Фан”. 2008.49-бет

5. Умарова 3.А. Бошланғич таълимда педагогик жараён. // Муғаллим хам узликсиз билимлендириў. Илмийметодик журнал. ISSN 2181-7138. №1 2021 й. 70-74-бет.

6. Mamadaliyev K.R., Jabborova O.M., Umarova Z.A., Abdullaeva B.P. Creation of a New Generation of Teaching Literature A Requirement of Modernity // SCOPUS International Journal of Psychosocial Rehabilitation, Vol. 24, Special Issue 1, 2020.

7. Жабборова Онахон Маннаповна, Ташпулатова Дилором Мукимовна, Бошланғичсинфўқитувчиларигақўйил адиганталаблар. Academic research in educational sciences, Issue 3, 2021, pp 575-5827.

8. Жабборова О.М., Умарова 3.А. Тарбия фанини кластер усулида ўқитишдапедагогикконфликтларниба ртарафэтиш. Academic research in educational sciences, Issue 1, 2021, pp 582-587. $\begin{array}{llr}\text { 9. Наримбетова } & \text { 3.А. УЧИТЕЛЬ- } \\ \text { НРАВСТВЕННЫЙ } & \text { ПРИМЕР ДЛЯ }\end{array}$
УЧЕНИКА. ACADEMIC RESEARCH IN EDUCATIONAL SCIENCES VOLUME 2

10. | Кузманова Г.Б., Н.А.Бекетов Use of Historical Materials In Teaching Mathematics In Continuous Education. The american journal of social science and education innovations, Volume 2 Issue 9, 2020, ISSN 2689-100X, 2(09), 531-537.12.14.

11. Кузманова Г.Б.UMUMIY O’RTA TA'LIM MAKTABLARIDA MATNLI MASALALARNING TA'LIMIY AHAMIYATI. ACADEMIC RESEARCH IN EDUCATIONAL SCIENCES, 2(3), 11541159

12. Abdullaeva B.P. Corruption in the field of education: assessments and ways to address. “Тенденции и перспективи развития науки и образования в условиях

глобализации".Международной научно-практической интернетконференции. г.Переяслав,

Украина.2020 год 30

13. Abdullaeva B.P. Babaraximova B.P. Pardaev B.P.Using information and communication technologies in teaching process of various primary European Journal of Research and Reflection in Educational Sciences, 8 (10), 67-70. Progressive Academic Publishing, UKwww.idpublications.org 14.10.2020.

14. Abdullaeva B.P. Abdullaev F.T. Organization of Swimming Lessons In Preschool Institutions THE AMERICAN JOURNAL OF SOCIAL SCIENCE AND EDUCATION INNOVATIONS. JULY 2020[ TAJSSEI]322ISSN (e):2689-100X DOI: https://doi.org/10.37547/tajssei/Volum 
CURRENT RESEARCH JOURNAL OF PEDAGOGICS 2(8): 110-116, August

2021 DOI: https://doi.org/10.37547/pedagogics-crjp-02-08-24

ISSN 2767-3278

(C)2021 Master Journals

Crossref dof 81 Google

Accepted 26 ${ }^{\text {th }}$ August, 2021 \& Published $31^{\text {th }}$ August, 2021

e02Issue 07-423.

15. Abdullayeva, B.P., \& Babaraximova, B. P. (2020). MAKTABGACHA TA'LIM MUASSASASIDA FUTBOL DARSLARINI TASHKIL ETISH METODIKASI. Academic Research in Educational Sciences http://ares.uz/jurnallarsahifasi/ares-vol-1-no-3-20204.

16. Abdullaeva B.P. ACADEMICIA: An International Multidisciplinary Research Journal https://saarj.com ORGANIZATION AND METHODOLOGY OF CONDUCTING FOOTBALL LESSONS

IN A PRESCHOOL INSTITUTION 650655 10.5958/2249-7137.2021.00098. 